\title{
Nesting substrata, colony success and productivity of the wasp Mischocyttarus cassununga
}

\author{
Mariana M. de Castroํ, Daniela L. Guimarães de Avelarr ${ }^{1}$, André R. de Souza² \& Fábio Prezoto ${ }^{1}$
}

\begin{abstract}
${ }^{1}$ Laboratório de Ecologia Comportamental e Bioacústica - LABEC, Universidade Federal de Juiz de Fora. Campus Universitário, Bairro Martelos, 36036-900 Juiz de Fora - MG, Brazil. marimc.jf@gmail.com, dlguimaraes@yahoo.com.br, fabio.prezoto@ufjf.edu.br

${ }^{2}$ Laboratório de Entomologia, Universidade Federal de Viçosa. Avenida Peter Henry Rolfs s/n, 36571-000 Viçosa - MG, Brazil. andrebioufjf@gmail.com
\end{abstract}

\begin{abstract}
Nesting substrata, colony success and productivity of the wasp Mischocyttarus cassununga. Colonies of the wasp Mischocyttarus cassununga (von Ihering, 1903) are easily found in urban areas. However, in spite of the massive presence of this species in cities, little is known about its nesting habits, colony success and productivity. The present study aimed at answering the following questions: What are the substrates used for nesting by $M$. cassununga? What is the main foundation strategy adopted by $M$. cassununga in urban areas: a solitary female or associative foundation? Is there a relationship between foundation strategies and colony success? Is the total number of cells per nest related to the number of adults produced? The study was conducted in Juiz de Fora, southeastern Brazil, from December 2006 to November 2007. Nesting in man-made substrata seems to be a common strategy in $M$. cassununga (90.9\%), with preference for nest building with a horizontal comb facing north. The colonies were established mainly by groups of foundresses $(67.6 \%)$, with a success of $84 \%$. The number of brood cells produced per nest was $71.74 \pm 45.25$ (18-203), and it was positively correlated with the number of adults produced. Hence, we can say that the nests founded by $M$. cassununga are located mainly in man-made substrata and mostly founded by a group of females. The cell reuse behavior increases the number of adults produced, as it optimizes foraging. These characteristics together with its behavior and nesting habits promote the success of this species in thriving in urban environments.
\end{abstract}

KEYWORDS. Hymenoptera; Insecta; social wasp; urban environment; Vespidae.

Wasps of the genus Mischocyttarus Saussure, 1853 have an independent nest foundation strategy and a primitive social organization; their colonies rarely exceed one hundred individuals (Jeanne 1972, 1991; Prezoto et al. 2004). In tropical regions, foundation occurs at any time of the year by one solitary female (haplometrosis) or associatively by a group of females (pleometrosis) (Jeanne 1972; Poltronieri \& Rodrigues 1976; Giannotti 1998; Penna et al. 2007b). Associative foundations may promote several advantages, such as higher productivity and survival rates, until workers emerge. In addition, associative foundations can assure a higher survival rate if the dominant female dies and may provide more effective defense against natural enemies (West Eberhard 1969; Jeanne 1975; Itô 1985).

The substrates selected by wasps for nesting provide the nests with crypticness. In the wild the foundation may occur under leaves, trunks, and in natural cavities (Jeanne 1991), whereas in urban areas, the colonies are frequently found in man-made structures, which shows a high synanthropism of the species (Fowler 1983; Lima et al. 2000; Prezoto et al. 2007; Alvarenga et al. 2010).

The Neotropical wasp Mischocyttarus cassununga (von Ihering, 1903) is easily found in southeastern Brazil. Its nest is composed of a single bare comb, attached to the substrate by an eccentric peduncle (Richards 1978). In spite of its massive presence in urban areas, little is known about its nesting habit, colony success, and productivity in this environment.

For these reasons, we intend to answer the following questions: What are the substrates used for nesting by $M$. cassununga? What is the main foundation strategy adopted by $M$. cassununga in urban areas: solitary female or associative foundation? Is there a relationship between foundation strategies and colony success? Is the total number of cells per nest related to the number of adults produced? Responses to these questions will promote a better understanding of the adaptation of $M$. cassununga in the occupation of urban areas.

\section{MATERIAL AND METHODS}

Study area and period. We conducted the study from December 2006 to November 2007 at the campus of the Federal University of Juiz de Fora, a site composed of green areas with recovered vegetation and buildings. This anthropic area is located at the municipality of Juiz de Fora, state of Minas Gerais, southeastern Brazil (21 $46^{\circ} \mathrm{S} 43^{\circ} 21^{\prime} \mathrm{W}$; average altitude of $678 \mathrm{~m}$ ).

Nesting substrata. To collect information about the foundation pattern of colonies of $M$. cassununga colonies, we made weekly visits to the colonies, preferably in the late afternoon $(5 \mathrm{pm})$, when the individuals were finishing their foraging activities, allowing a more precise counting of the 
number of foundresses present in the colony. We checked the green areas and the building during the visits and recorded the following parameters: substratum type used for the colony foundation $(\mathrm{n}=165)$, that was classified in two categories: man-made substrata and vegetation; position of the comb, height of the colony from the ground $(n=165)$; and direction of the comb: vertical or horizontal $(n=46)$, measured with a compass.

Colony success. We considered a successful colony the one that reached the post-emergence phase (according to Jeanne 1972), with the emergence of at least one adult. We monitored colonies from the foundation phase to the first adult's emergence and/or abandonment of the nest. We considered an unsuccessful colony the one that, after three consecutive visits, lacked adults, larval immatures, egg postures and new cells. For the analyses, we recorded the total number of cells of the colony at the end of the pre-emergence phase $(n=74)$ and the number of females involved during the colony foundation phase $(\mathrm{n}=74)$.

Nest productivity analysis. We sampled 19 inactive nests that have already completed their colonial cycle. The nests were dissected and the information schematized in maps in standardized worksheets. For each nest, we recorded the following parameters: total number of cells, total number of productive cells, total number of adults produced (by the counting of meconium layers deposited in the cells), number of adults produced per cell and the ratio of produced adults/ cells. We also recorded information on width and height (from the base to the top of the cell) of 438 cells, by the counting of meconium layers and their height inside the cell, using a caliper (Oliveira et al. 2010).

Statistical analysis. We used the Spearman test to calculate correlations between (a) the number of foundresses and the number of cells in the colony at the end of the pre-emergence phase; (b) the total number of cells and the total number of adults produced by the colonies; (c) the height of cells and the number of meconium layers. To test for differences between the categories used for nesting (man-made substrata and vegetation) and between the number of colonies constructed with vertical and horizontal comb we used the corrected Chi-squared test (Yates) $(\mathrm{p}<0.05)$. To apply the tests we used the freeware software Bioestat 5.0.

\section{RESULTS}

Nesting substrata. The number of nests on man-made substrata $(\mathrm{n}=150 ; 90.89 \%)$ was significantly larger $\left(\chi^{2}=\right.$ $110.455 ; \mathrm{p}<0.001)$ than the vegetation substratum $(n=15$; $9.09 \%$ ). In man-made category we found colonies on several types of substrata: masonry $(\mathrm{n}=75 ; 45.45 \%)$, metal ( $\mathrm{n}$ $=56 ; 33.93 \%)$, roof tiles $(\mathrm{n}=12 ; 7.27 \%)$, glass $(\mathrm{n}=3 ; 1.81 \%)$, wood $(\mathrm{n}=2 ; 1.21 \%)$, plastic $(\mathrm{n}=1 ; 0.61 \%)$, and paper $(\mathrm{n}=$ $1 ; 0.61 \%)$. In the vegetation substratum the nests were found only under leaves.

The average height of the colonies from the ground was $2.55 \pm 0.90 \mathrm{~m}(0.40-7.50)$. The number of nests with verti- cal peduncle and horizontal comb $(\mathrm{n}=119)$ differed significantly $\left(\chi^{2}=31.418 ; \mathrm{p}<0.0001\right)$ from the nests with horizontal peduncle and vertical comb $(n=46)$ (Fig. 1). Most colonies were north-oriented, between northwest and northeast, $271^{\circ}$ to $90^{\circ}(73.91 \% ; \mathrm{n}=34)$.
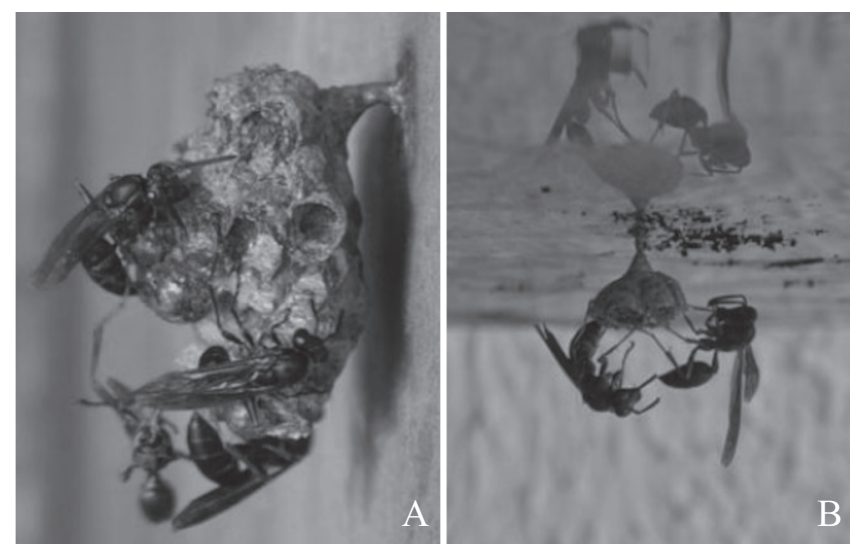

Fig. 1. Colonies of Mischocyttarus cassununga founded in man-made substrata: (A) horizontal peduncle and vertical comb and (B) vertical peduncle and horizontal comb.

Colony success. Most $M$. cassununga colonies were founded by a group of foundresses $(n=50 ; 67.57 \%)$ of which $84 \%(n=42)$ obtained success. Colonies founded by a solitary female were less frequent $(\mathrm{n}=24 ; 32.43 \%)$ and had a success of $37.5 \%(n=9)$. Groups of two and three foundresses obtained a success of approximately $77 \%$, whereas groups of four females had better chance of fully developing $(91.67 \%)$, and five or more females achieved complete success $(100 \%)$ (Table I). There was a positive correlation between the number of females involved in the foundation and the total number of cells produced at the end of the pre-emergence phase $(r=0.9286 ; p=0.0009)$.

Table I. Frequency of foundation of colonies of Mischocyttarus cassununga according to the number of foundress females, success of colonies, and number of brood cells at the end of the pre-emergence phase (average, standard deviation, and range) in 74 colonies founded.

\begin{tabular}{|c|c|c|c|c|}
\hline $\begin{array}{l}\text { Number of } \\
\text { foundresses }\end{array}$ & $\mathrm{N}$ & $\begin{array}{l}\text { Frequency } \\
(\%)\end{array}$ & $\begin{array}{l}\text { Success of } \\
\text { colonies (\%) }\end{array}$ & $\begin{array}{l}\text { Number of cells at the end of the } \\
\text { pre-emergence phase (range) }\end{array}$ \\
\hline 1 & 24 & 32.43 & 37.50 & $10.78 \pm 4.82(5-18)$ \\
\hline 2 & 18 & 24.32 & 77.78 & $12.78 \pm 3.94(6-21)$ \\
\hline 3 & 13 & 17.57 & 76.92 & $17.60 \pm 7.97(10-35)$ \\
\hline 4 & 12 & 16.22 & 91.67 & $24.36 \pm 7.34(12-36)$ \\
\hline 5 & 2 & 2.71 & 100.00 & $34.0 \pm 4.24(31-37)$ \\
\hline 6 & 1 & 1.35 & 100.00 & $40.00 \pm 0$ \\
\hline 7 & 3 & 4.05 & 100.00 & $33.67 \pm 8.5(25-42)$ \\
\hline 9 & 1 & 1.35 & 100.00 & $45.00 \pm 0$ \\
\hline
\end{tabular}

Nest productivity. The average number of cells produced per nest by $M$. cassununga was $71.74 \pm 45.25$ (18-203); the percentage of unproductive cells was $47.86 \pm 9.54$ (32-61.1\%) and the average number of adults produced per nest was 63.63 \pm 58.43 (12-243). The average number of individuals pro- 
duced per cell was 0.78 ; we recorded a single cell being used five times at most (Table II). There was a positive correlation $(r=0.9354 ; p<0.0001)$ between the total number of cells and the total number of adults produced in the colonies.

The unproductive cells of $M$. cassununga were concentrated in the periphery of the comb, whereas the cells that were used more times were located in the central region, the oldest in the comb. There was a positive correlation between the height of the cells and the number of meconium layers ( $\mathrm{r}$ $=0.6527 ; p<0.0001)$. The average width of the cells did not vary much in relation to the number of times they were used (2-3 mm) (Table III).

\section{DISCUSSION}

Nesting substrata. Some species of Mischocyttarus use human constructions as nesting substrata, even when elements from the natural environment, such as plants, are available (Jeanne 1972; Hermann \& Chao 1984; Raposo-Filho \& Rodrigues 1984; Simões et al. 1985; Lima et al. 2000; Alvarenga et al. 2010; Torres et al. 2011). The vegetation present in the anthropic environment was used by a small number of colonies, which might be attributed to the fragility of the plants, mostly species used for gardening that did not offer appropriate support for the nest, and exposed the nest to the weather. Characteristically, the vegetation in these areas consists of shrubs, small (usually less than $1 \mathrm{~m}$ high) and with small and deciduous leaves.

The results demonstrated the synantropism of $M$. cassununga in relation to the constructions with human interference. This can be explained in part by the fact that in this type of environment the colonies had better protection from human interference, bad weather, and direct sunlight, which can result in a higher chance of success. Other authors (Simões et al. 1985; Lima et al. 2000; Torres et al. 2011) also observed a preference of species of the genus for nesting in human buildings, in particular in sites protected from direct sunlight and rain.

The average height observed for nests of M. cassununga can be explained by the fact that most nests were found in man-made substrates, which have mostly predefined height such as for windows, ceilings, and roof tiles, which increases the height of the nests and making them discrete in relation to human perception. This result agrees with the standard height for wasp nests with independent foundation (genera Polistes and Mischocyttarus) observed by Alvarenga et al. (2010) in urban gardens in the city of Juiz de Fora, Brazil. Also, according to Lima et al. (2000), nests built below two meters in height are mostly likely to be destroyed or abandoned.

Table II. Comparative data of the productivity of 19 nests of Mischocyttarus cassununga collected in an urban area of the municipality of Juiz de Fora, southeastern Brazil.

\begin{tabular}{|c|c|c|c|c|c|c|c|c|c|}
\hline \multirow[t]{2}{*}{ Colony number } & \multirow[t]{2}{*}{ Total number of cells } & \multicolumn{5}{|c|}{ Number of utilizations } & \multirow[t]{2}{*}{$\%$ of unproductive cells } & \multirow[t]{2}{*}{ Adults produced } & \multirow[t]{2}{*}{ Adults produced/cell } \\
\hline & & 1 & 2 & 3 & 4 & 5 & & & \\
\hline 1 & 18 & 4 & 1 & 2 & - & - & 61.10 & 12 & 0.66 \\
\hline 2 & 30 & 15 & - & - & - & - & 50.00 & 15 & 0.50 \\
\hline 3 & 35 & 12 & 2 & - & - & - & 60.00 & 16 & 0.46 \\
\hline 4 & 35 & 12 & 3 & 1 & - & - & 54.30 & 19 & 0.54 \\
\hline 5 & 35 & 14 & 5 & - & - & - & 45.70 & 24 & 0.68 \\
\hline 6 & 43 & 18 & 7 & 3 & - & - & 34.90 & 41 & 0.95 \\
\hline 7 & 44 & 18 & 3 & - & - & - & 52.30 & 24 & 0.54 \\
\hline 8 & 44 & 19 & 5 & - & - & - & 45.40 & 29 & 0.66 \\
\hline 9 & 52 & 16 & 7 & - & - & - & 57.70 & 30 & 0.57 \\
\hline 10 & 68 & 21 & 9 & - & - & - & 55.90 & 39 & 0.57 \\
\hline 11 & 71 & 26 & 13 & 9 & - & - & 32.40 & 79 & 1.11 \\
\hline 12 & 76 & 21 & 10 & 3 & 1 & - & 53.90 & 54 & 0.71 \\
\hline 13 & 80 & 15 & 11 & 11 & 8 & 1 & 42.50 & 107 & 1.34 \\
\hline 14 & 83 & 9 & 18 & 6 & - & - & 60.20 & 63 & 0.76 \\
\hline 15 & 84 & 33 & 16 & - & - & - & 41.60 & 65 & 0.77 \\
\hline 16 & 108 & 34 & 15 & 7 & 7 & 6 & 35.20 & 143 & 1.32 \\
\hline 17 & 113 & 47 & 13 & - & - & - & 46.00 & 73 & 0.64 \\
\hline 18 & 141 & 39 & 16 & 11 & 6 & 1 & 48.20 & 133 & 0.94 \\
\hline 19 & 203 & 76 & 30 & 23 & 7 & 2 & 32.00 & 243 & 1.20 \\
\hline Average & 71.74 & - & - & - & - & - & 47.86 & 63.63 & 0.78 \\
\hline
\end{tabular}

Table III. Height and width (average, standard deviation, and range) of the cells in relation to the meconium layers that have been deposited in the bottom as the cells are used to produce adult individuals of Mischocyttarus cassununga $(\mathrm{n}=438)$.

\begin{tabular}{cccc}
\hline Number of meconium layers & Number of cells $(\mathrm{n})$ & Height of the layers $(\mathrm{mm})$ & Height of the cells $(\mathrm{mm})$ \\
\hline 1 & 270 & $0.97 \pm 0.11(0.5-1)$ & $10.73 \pm 1.80(6-18)$ \\
2 & 107 & $2.02 \pm 0.19(2-3)$ & $12.90 \pm 1.90(10-19)$ \\
3 & 39 & $3.22 \pm 0.44(2.5-4)$ & $15.41 \pm 2.12(12-20)$ \\
4 & 15 & $4.60 \pm 0.63(4-6)$ & $16.60 \pm 2.67(12-20)$ \\
5 & 7 & $5.71 \pm 0.75(5-7)$ & $18.57 \pm 1.51(16-21)$ \\
\hline
\end{tabular}


In this study, the construction pattern of colonies of $M$. cassununga recorded may be explained by the search for protection against bad weather. In studies carried out in Brazil, colonies of Mischocyttarus drewseni Saussure, 1857 were mainly oriented to the west probably because in the study site storms come from the east (Jeanne 1972). Nests of $M$. cerberus styx (Richards, 1940) were oriented to the east towards the foraging area (Giannotti 1999). Montagna et al. (2010) did not find a preference for a particular nest orientation in Mischocyttarus consimillis Zikán, 1949, and also observed that the colonies may be founded horizontally, vertically or inclined.

Colony success. The foundation of a colony by a group of females was the predominant nesting strategy observed and resulted in the highest success in adult production. This strategy can be interpreted as optimal, since ecological pressures, such as parasitism and usurpation, social pressures, and an increase in survival levels are associated (West Eberhard 1969; Itô 1985).

The high index of failure of colonies founded by solitary females may be explained by abandon or death of the female during the initial phase of colony establishment. Wasps can migrate or associate themselves with other foundresses, which characterizes abandonment. On the other hand, the death of the foundress can be associated with its totipotency, which demands high energy and results in high exposure to risks such as predation (Jeanne 1991).

Dispute for hierarchical dominance is cited by Prezoto et al. (2004) as an event that can frequently cause the migration of females from one colony to another, where their hierarchical position can be more rewarding. Ultimately, this situation may contribute to the failure of these colonies, due to the loss of workers.

Nest productivity. The average number of cells and adults produced in the present study overpassed those found in other studies on M. cassununga (Gobbi \& Simões 1988; Penna et al. 2007b). For other species of the genus, such as M. cerberus (Giannotti 1998; Penna et al. 2007b), M. drewseni (Penna et al. 2007a), and M. consimillis (Montagna et al. 2010), productivity, unproductive cells, and number of times a single cell was used varied greatly. These differences may reflect intrinsic biological characteristics of each species, as well as adaptive responses to the environments where the studies were conducted, which hinders comparisons between the species.

Likewise other species of the genus (Penna et al. 2007a, b; Montagna et al. 2010), M. cassununga presents a high rate of cell reuse in populous colonies. This behavior seems to promote reduction in work, which reduces the need for foraging for material to build new cells. The central cells of the comb had a higher frequency of use due to the discoidal pattern in nest building, where the central cells are older and thus mostly likely to be reused.

In urban areas, we can say that the nests founded by $M$. cassununga are located mainly in man-made substrata; they are mostly founded by a group of females. The higher the number of foundresses, the higher the chance of colony suc- cess. Cell reuse behavior increases the number of adults produced, as it optimizes foraging and reduces the need for searching for construction material and, therefore, increases the time for foraging for food. These characteristics, together with its behavior and nesting habits, promote the success of $M$. cassununga in thriving in urban environments.

\section{ACKNOWLEDGMENTS}

We are grateful to Bruno Corrêa Barbosa for his contribution and to the Fundação de Amparo à Pesquisa de Minas Gerais (FAPEMIG), Conselho Nacional de Desenvolvimento Científico e Tecnológico (CNPq) (to Fábio Prezoto, 307264/ 2010-6 and 310713/2013-7 under grant 143246/2011-9) and Coordenação de Aperfeiçoamento de Pessoal de Nivel Superior (CAPES) for their financial support.

\section{REFERENCES}

Alvarenga, R.B., Castro, M.M., Santos-Prezoto, H.H. \& Prezoto, F. 2010. Nesting of Social Wasps (Hymenoptera, Vespidae) in Urban Gardens in Southeastern Brazil. Sociobiology 55: 445-452.

Fowler, H.G. 1983. Human effects on nest survivorship of urban synanthropic wasps. Urban Ecology 7: 137-143.

Giannotti, E. 1998. The colony cycle of the social wasp, Mischocyttarus cerberus styx Richards, 1940 (Hymenoptera, Vespidae). Revista Brasileira de Entomologia 41: 217-224.

Giannotti, E. 1999. Arquitetura de ninhos de Mischocyttarus cerberus styx Richards, 1940 (Hymenoptera, Vespidae). Revista Brasileira de Zoociências 1: 7-18.

Gobbi, N. \& Simões, D. 1988. Contribuição ao entendimento do ciclo básico de colônias de Mischocyttarus (Monocyttarus) cassununga von Ihering, 1903 (Hymenoptera, Vespidae). Anais da Sociedade Entomológica do Brasil 17: 421-436.

Hermann, H.R. \& Chao, J.-T. 1984. Nesting biology and defensive behavior of Mischocyttarus (Monocyttarus) mexicanus cubicola (Vespidae: Polistinae). Psyche 91: 51-65.

Itô, Y. 1985. A comparison of intra-colony aggressive behaviours among five species of Polistine wasps (Hymenoptera, Vespidae). Zeitschrift für Tierpsychologie 68: 152-167.

Jeanne, R.L. 1972. Social biology of the neotropical wasp Mischocyttarus drewseni. Bulletin of the Museum of Comparative Zoology 144: 63-150.

Jeanne, R.L. 1975. The adaptiveness of social wasp nest architecture. Quarterly Review of Biology 50: 267-87.

Jeanne, R.L. 1991. The swarm-founding Polistinae, p.191-231. In: Ross, K.G. \& Matthews, R.W. (eds.). The social biology of wasps. New York, Cornell University Press, xiv+696 p.

Lima, M.A.P., Lima, J.R. \& Prezoto, F. 2000. Levantamento dos gêneros, flutuação das colônias e hábitos de nidificação de vespas sociais (Hymenoptera, Vespidae), no campus da UFJF, Juiz de Fora, MG. Revista Brasileira de Zoociências 2: 69-80.

Montagna, T.S., Torres, V.O., Fernandes, W.D. \& Antonialli-Junior, W.F. 2010. Nest Architecture, Colony Productivity, and Duration of Immature Stages in a Social Wasp, Mischocyttarus consimilis. Journal of Insect Science 10: 1-12.

Oliveira, S.A., de Castro, M.M. \& Prezoto, F. 2010. Foundation pattern, productivity and colony sucess of the paper wasp, Polistes versicolor. Journal of Insect Science 10: 1-10.

Penna, M.A.H., Gobbi, N. \& Giacomini, H.C. 2007a. An evaluation of the productivity of Mischocyttarus drewseni in a semi-urban environment (Hymenoptera: Polistinae). Sociobiology 50: 113-120.

Penna, M.A.H., Gobbi, N., Giacomini, H.C., Prezoto, F. \& Gonçalves, F.M.F. 2007b. Comparative productivity of Mischocyttarus cerberus styx 
(Richards, 1940) and Mischocyttarus cassununga Saussure (von Ihering, 1903 ) in an anthropic environment as evaluation for differences in ecological strategies. Revista Brasileira de Zoociências 9: 205-212.

Poltronieri, H.S. \& Rodrigues, V.M. 1976. Vespídeos sociais: estudos de algumas espécies de Mischocyttarus Saussure, 1853 (Hymenoptera, Vespidae, Polistinae). Dusenia 9: 99-105.

Prezoto, F., Vilela, A.P.P., Lima, M.A.P., D’Ávila, S., Sinzato, D.M.S., Andrade, F.R., Santos-Prezoto, H.H. \& Giannotti, E. 2004. Dominance hierarchy in different stages of development in colonies of the primitively eusocial wasp Mischocyttarus cassununga (Hymenoptera, Vespidae). Sociobiology 44: 379-390.

Prezoto, F., Ribeiro-Júnior, C., Oliveira-Cortes, S.A. \& Elisei, T. 2007. Manejo de vespas e marimbondos em ambiente urbano, p.123-126. In: Pinto, A.S., Rossi, M.M. \& Salmeron, E. (orgs.). Manejo de Pragas Urbanas. Piracicaba, Editora CP2, xiv+192 p.
Raposo-Filho, J.R. \& Rodrigues, V.M. 1984. Habitat e local de nidificação de Mischocyttarus (Monocyttarus) extinctus Zikán, 1935 (Polistinae, Vespidae). Anais da Sociedade Entomológica do Brasil 13: 19-28.

Richards, O.W. 1978. The social wasps of the Americans, excluding the Vespinae. London, British Museum (Natural History), xiv $+580 \mathrm{p}$.

Simões, D., Gobbi, N. \& Batarce, B.R.M. 1985. Mudanças sazonais na estrutura populacional em colônias de três espécies de vespas do gênero Mischocyttarus (Hymenoptera, Vespidae). Naturalia 10: 89-105.

Torres, V.O., Montagna, T.S., Fernandes, W.D. \& Antonialli-Junior, W.F. 2011. Colony cycle of the social wasp Mischocyttarus consimilis Zikán (Hymenoptera, Vespidae). Revista Brasileira de Entomologia 55: $247-252$.

West Ebehard, M.J. 1969. The social biology of Polistine wasps. Miscellaneous Publications of the Museum of Zoology of the University of Michigan 140: 1-101. 